\title{
Media Digital Literacy Program in Improving Parental Mediation Efficacy with Community Nursing Approach
}

\author{
Umi Hani ${ }^{1 *}$, Sonhaji ${ }^{1}$, Clara Novita Anggraini ${ }^{2}$ \\ ${ }^{1}$ Department of Community Health Nursing, STIKes Karya Husada Semarang, Indonesia \\ ${ }^{2}$ Communication Science, Communication and Business Faculty, Telkom University, Indonesia \\ *umi.hani.ners@gmail.com
}

\begin{abstract}
Indonesian children suffer from mental disorders due to an addiction to gadgets. Parents' efficacy determines the mediation style that parents took to prevent some negative impacts of gadgets. This study aimed to assess the effect of a digital media literacy program on mothers' self-efficacy in parental mediation. This study used a quantitative design with a quasi-experimental approach pre and post-test with a control group. The samples were mothers of distance learned students in an elementary school. The research started with initial screening by filling out a questionnaire on gadgets usage for elementary students. The treatment group $(n=35)$ enrolled in 4 online meeting sessions with seven respondents per small group. In the same research period, the control group $(n=35)$ enrolled in only one big class session about parental mediation. After the intervention, the sample measured the level of maternal self-efficacy. Univariate statistics determined the respondent's characteristics, parental mediation of the use of gadgets in children, and the mother's self-efficacy in parental mediation before and after the program. The data were not normally distributed using the Shapiro Wilk test. Thus differences in maternal self-efficacy before and after treatment were analyzed using Wilcoxon. Simultaneously, differences in self-efficacy between the treatment group and the control group were analyzed using Mann Whitney. Digital media literacy significantly increased mothers' self-efficacy in mediating the use of gadgets by children $(\mathrm{p}<0.05)$. Digital media literacy includes the skills to communicate with others so that self-confidence increases with literacy. However, literacy built with a community group approach can help build trust through the group processes. Digital media literacy with a community health approach affects mothers' self-efficacy in mediating the use of gadgets by children. Parental mediation needs to be optimized to prevent gadget addiction in children. Literacy programs can be a recommendation but require nurse assistance to build maternal self-efficacy.
\end{abstract}

Keywords: Gadget, Digital Literacy, Parental Mediation, Self-Efficacy

Received November 2, 2020; Revised November 113 2020; Accepted November 20, 2020

STRADA Jurnal Ilmiah Kesehatan, its website, and the articles published there in are licensed under a Creative Commons Attribution-ShareAlike 4.0 International License. 


\section{STRADA Jurnal Ilmiah Kesehatan}

DOI: $10.30994 /$ sjik.v9i2.522

ISSN: 2252-3847 (print); 2614-350X (online)

Vol.9 No.2 November 2020 Page.1779-1787

\section{BACKGROUND}

The development of information and communication technology is very rapid, mainly triggered by internet-based media development. This technology has touched various aspects of life, including health, education, agriculture, communication, politics, and others, easily reached with just a gadget. Gadgets are electronic instruments that have a practical function in helping and facilitating social work. Various features on gadgets that continue to evolve, such as cameras, music players, calculators, social media, games, calendars, telephones, and writing messages, have made gadgets in great demand by various groups, including children ${ }^{(1,2)}$.

A survey by the Indonesian Internet Service Providers Association stated that internet usage in Indonesia continues to increase. In 2017, internet users reached 143.26 million or more than $50 \%$ of Indonesia's population ${ }^{(1)}$. The development of the internet also has a significant influence on society's formation and change, especially its use at the age of children at risk of negative impacts. Advances in information technology are essential in carrying out various aspects of life, especially in the current COVID-19 pandemic. The government's policy to close schools and implement learning from home has made the community more exposed to gadgets, including school-age children. Research on parental supervision patterns of children's activities in cyberspace explains that parents generally have a relatively adequate understanding of the internet's dangers. However, not all parents understand all aspects of internet risk and then take the protection ${ }^{(3)}$. The use of media has an impact on cognitive, imitation, and behavioral impacts. Information that is not following the child's development level will form a negative character of the child. Therefore, parents play a critical role in sorting and choosing exposure to gadgets and media for children to be free from negative influences ${ }^{(4)}$.

Children constitute a "special audience" in media studies because of their youth and life experiences ${ }^{(5)}$. Therefore, parents are often involved in children's interactions with gadgets. This parental involvement activity is known as mediation, which refers to parents' interaction with their children and the media. The form of parental mediation will affect how children use gadgets. Parental mediation gives parents a choice to determine their attitude in monitoring gadgets' use in children ${ }^{(6)}$.

Parents' concerns about the negative impact of gadgets on children affect self-efficacy in supervising gadgets in children. Self-efficacy is a person's belief in his ability to perform specific tasks. Self-efficacy in parenting is defined as a parent's belief in influencing children and the environment that supports children's development. Self-efficacy can be obtained, studied, and developed from four sources of information, which are stimulation of task achievement. These are vicarious experiences, experiences of others (role models), verbal persuasion, and physical and emotional conditions ${ }^{(7)}$.

This study aimed to determine the effect of digital media literacy on maternal selfefficacy in parental mediation of gadgets in children, especially during the COVID-19 pandemic. The research problem's formulation is "is digital media literacy effective in increasing the self-efficacy of mothers in monitoring the use of gadgets in children?". This research's scope is the measurement of the self-efficacy of mothers who have elementary school-age children with exposure to gadgets more than 2 hours per day.

\section{METHODS}

The study was a quasi-experimental design with a control group pre and post-test. It was conducted between September to October 2020. The population was mothers of school-age children who use the gadget in 2 hours of minimal per day. A total of 74 mothers were 


\section{STRADA Jurnal Ilmiah Kesehatan}

DOI: $10.30994 /$ sjik.v9i2.522

ISSN: 2252-3847 (print); 2614-350X (online)

Vol.9 No.2 November 2020 Page.1779-1787

contacted for sample selection, and all agreed to participate. Each participant was informed about the study's nature, purpose, benefits, the right to refuse or withdraw at any time, as well as the obtained data confidentiality. The study was conducted with 74 respondents who met the inclusion criteria. Participants were selected based on inclusion criteria: (1) have school-aged children who use gadgets more than 2 hours per day, (2) literate, and (3) have facilities to participate in the online meeting. Respondents who did not enroll in the entire four sessions were excluded. Information on the capacity to give informed consent was also provided during this process. The experimental group $(n=37)$ were enrolled in a media digital literacy program (watching videos, reading a parental mediation handbook, participating in four courses of parental mediation, telephone follow-up, and positive reinforcement), while the control group $(n=37)$ enrolled in one session about parental mediation. The self-efficacy in parental mediation of the post-test outcome variables of the experimental and control groups was carried out. Once consent was obtained, the parental mediation activity and self-efficacy were assessed. Demographic details were collected from the participant.

\section{Interventions}

The day before the first session of the digital media literacy program, the respondents' parental mediation activity and self-efficacy were measured using a parental mediation questionnaire. Respondents were also explained about the program.

Respondents were included in some WhatsApp groups (6-10 respondents). Media digital literacy program consisted of four sessions of education. The topic was about gadget use in children: positives and negatives and health impacts. The three other sessions were conducted online or by phone call. The topics were the ability to access and recognize messages and message patterns, analyze and evaluate messages received, and parental mediation on gadgets in children. In every session, progressive muscle relaxation was conducted together. Respondents' self-efficacy was then observed the day after the fourth session for the post-test.

\section{Instruments}

Respondents' self-efficacy before and after the intervention was assessed through the parental mediation self-efficacy questionnaire. It is a brief self-report questionnaire of selfefficacy that includes items assessing the following aspects of the parental mediation activity: active mediation of internet use, restrictive mediation, active mediation of internet safety, monitoring, and technical mediation (8). Respondents report on the frequency with which they performed various activities over the previous seven days. Before the final analysis, data were screened for normality assumption. The normality test of data using the Shapiro-Wilk test revealed that the data was not normally distributed. The respondents' demographic characteristics are reported as numbers and percentage distributions, and the Wilcoxon test was used to analyze the effect of the program on self-efficacy. The study was declared to have passed the ethical review by the Research Ethics Committee Karya Husada Semarang College No.60/KH.KEPK/KT/I/2020.

\section{RESULT}

\section{Descriptive characteristics of respondents}

Results showed that mean of either experimental group's or control group's respondents was 37.75 years old. The school-aged children of respondents in this study was 7.70 years old in 


\section{STRADA Jurnal Ilmiah Kesehatan}

DOI: $10.30994 /$ sjik.v9i2.522

ISSN: 2252-3847 (print); 2614-350X (online)

Vol.9 No.2 November 2020 Page.1779-1787

mean of experimental group, and 7.79 years old in control group. The descriptive characteristics of respondents showed in Table 1 and 2.

Table 1. Age and child-age characteristics of respondents

\begin{tabular}{lrrrrr}
\hline & \multicolumn{2}{c}{ Experiment Group } & \multicolumn{2}{c}{ Control Group } \\
\hline & \multicolumn{1}{c}{ Age } & \multicolumn{1}{c}{ Child-Age } & Age & \multicolumn{1}{c}{ Child-Age } \\
\hline \multirow{2}{*}{$\mathrm{N}$} & Valid & 35 & 35 & 35 & 35 \\
\cline { 2 - 6 } & Missing & 0 & 0 & 0 & 0 \\
\hline Mean & 37.75 & 7.70 & 37.75 & 7.79 \\
\hline Median & 37.50 & 8.00 & 38.00 & 8.00 \\
\hline Std. Deviation & 3.959 & 1.174 & 3.462 & 1.134 \\
\hline
\end{tabular}

Table 2. Occupation characteristics of respondents

\begin{tabular}{cllccc}
\hline & & \multicolumn{2}{c}{ Experimental Group } & \multicolumn{2}{c}{ Control Group } \\
\hline & Frequency & Percent & Frequency & Percent \\
\hline \multirow{3}{*}{ Valid } & Housewive & 19 & 55.0 & 16 & 45.0 \\
\cline { 2 - 6 } & Teacher & 5 & 15.0 & 5 & 15.0 \\
\cline { 2 - 6 } & Employer & 9 & 25.0 & 11 & 30.0 \\
\cline { 2 - 6 } & Civil & 2 & 5.0 & 3 & 10.0 \\
\cline { 2 - 6 } & Total & 35 & 100.0 & 35 & 100.0 \\
\hline
\end{tabular}

Mean of parental mediation self-efficacy increased after media digital literacy program both in experiment and control group. The details were showed in Table 3.

Table 3. The mean of parental mediation self-efficacy before and after the program

\begin{tabular}{lcc}
\multirow{2}{*}{ Group } & \multicolumn{2}{c}{ Mean \pm SD } \\
\cline { 2 - 3 } & Pre-test & Post-test \\
\hline Control & $31.95 \pm 10.61$ & $36.50 \pm 8.78$ \\
Experiment & $34 \pm 10.61$ & $37.50 \pm 8.17$ \\
\hline
\end{tabular}

\section{Self-Efficacy before and after intervention for experiment group}

The test statistics table showed that all the Asymp. Sig. value of five parental mediation scale were $<0.05$ (Table 4 and Table 5). These results indicated that there was a difference between the scale of the mediation before and after the intervention. Digital media literacy programs affected the self-efficacy of mothers in parental mediation.

Table 4. Experimental Group's Wilcoxon Test Statistics

\begin{tabular}{lcrrrrrr}
\hline & $\begin{array}{c}\text { EAMPost - } \\
\text { pre }\end{array}$ & $\begin{array}{c}\text { ESPost - } \\
\text { pre }\end{array}$ & $\begin{array}{c}\text { ERPost - } \\
\text { pre }\end{array}$ & $\begin{array}{c}\text { ETPost - } \\
\text { pre }\end{array}$ & \multicolumn{2}{c}{$\begin{array}{c}\text { EMPost - } \\
\text { pre }\end{array}$} & \multicolumn{2}{c}{$\begin{array}{c}\text { Tot Post - } \\
\text { Pre }\end{array}$} \\
\hline $\mathrm{Z}$ & $-2.962^{\mathrm{b}}$ & $-2.407^{\mathrm{b}}$ & $-3.342^{\mathrm{b}}$ & $-3.462^{\mathrm{b}}$ & $-3.351^{\mathrm{b}}$ & $-3.733^{\mathrm{b}}$ \\
\hline $\begin{array}{l}\text { Asymp. Sig. (2- } \\
\text { tailed) }\end{array}$ & .003 & .016 & .001 & .001 & .001 & .000 \\
\hline b. Based on negative ranks. & & & & & & \\
\hline
\end{tabular}

Table 5. Control Group's Wilcoxon Signed Ranks Test Statistics

\begin{tabular}{ccccccc}
\hline & $\begin{array}{c}\text { EAMPost - } \\
\text { pre }\end{array}$ & $\begin{array}{c}\text { ESPost - } \\
\text { pre }\end{array}$ & $\begin{array}{c}\text { ERPost - } \\
\text { pre }\end{array}$ & $\begin{array}{c}\text { ETPost - } \\
\text { pre }\end{array}$ & $\begin{array}{c}\text { EMPost - } \\
\text { pre }\end{array}$ & $\begin{array}{c}\text { Tot_Post - } \\
\text { Pre }\end{array}$ \\
\hline $\mathrm{Z}$ & $-1.925^{\mathrm{b}}$ & $-2.060^{\mathrm{b}}$ & $-3.269^{\mathrm{b}}$ & $-3.370^{\mathrm{b}}$ & $-2.863^{\mathrm{b}}$ & $-3.636^{\mathrm{b}}$ \\
\hline
\end{tabular}




\section{STRADA Jurnal Ilmiah Kesehatan}

DOI: $10.30994 /$ sjik.v9i2.522

\begin{tabular}{lrlllll}
\hline $\begin{array}{l}\text { Asymp. Sig. (2- } \\
\text { tailed) }\end{array}$ & .054 & .039 & .001 & .001 & .004 & .000 \\
\hline b. Based on negative ranks. \\
\hline
\end{tabular}

\section{Differents between intervention and control group}

Table 6. Mann-Whitney Test Statistics

\begin{tabular}{ll}
\hline & Self-efficacy post \\
\hline Mann-Whitney U & 167.500 \\
\hline Wilcoxon W & 377.500 \\
\hline$Z$ & -.882 \\
\hline Asymp. Sig. (2-tailed) & .378 \\
\hline Exact Sig. [2*(1-tailed Sig.)] & $.383 \mathrm{~b}$ \\
\hline a. Grouping Variable: Kelompok & \\
b. Not corrected for ties. & \\
\hline
\end{tabular}

Statistical analysis using the Mann-Whitney test indicated that there was no difference in self-efficacy scale prior and after media digital literacy program (Asymp. Sig 2 tailed $>0.05$ ) (Table 2). This showed that there was no effect of this program on improving selfefficacy in parental mediation.

\section{DISCUSSION}

Socio-demographic factors related with parental mediation

The study about socio-demographic factors associated with parental monitoring of children's screen-based media uses resulted in that age affected parental monitoring (more autonomy or independence). Parental monitoring also differed by ethnicity and household income. Parents reported more active mediation in families with higher household income, which implied the gadget use in children ${ }^{(9)}$.

Media literacy program

Media literacy involves a series of digital production skills that include creating, being critical, contributing, and consuming digital content. It is not only the simple development of interpretive skills. Media literacy skills have a positive correlation with positive behavior with the gadget. The higher a person's level of health knowledge, the more likely they are to lead a healthy lifestyle. Parents showed positive attitudes toward media, to the extent that they believed media exposure to be vital to children's development, and many disagreed with recommendations from expert sources regarding age-appropriate screen time ${ }^{(10)}$. Therefore, the role of nurses is critical as an educator in providing nutrition education. Without knowledge, health workers cannot expect people to understand the concepts needed to maintain their health ${ }^{(5)}$. Digital literacy programs must go beyond training or teaching the basic skills of how to use the technology and include the context of where and when to apply the skills, knowledge, and information ${ }^{(11)}$.

Gadgets are a form of technological development in circulation today. Devices are not only used by teenagers or adults but also by school children. School-age is too early for the introduction of gadgets. School-age children are more advised to play physical, intellectual skills, fantasy, and groups or teams. Parental involvement in children's interactions with gadgets is often known as mediation. ${ }^{(6)}$. he form of parental mediation will affect how children use gadgets. Parental mediation gives parents a choice to determine their attitude in monitoring gadgets' use in children ${ }^{(12)}$. Parents can modify or even prevent the negative 


\section{STRADA Jurnal Ilmiah Kesehatan}

DOI: $10.30994 /$ sjik.v9i2.522

ISSN: 2252-3847 (print); 2614-350X (online)

Vol.9 No.2 November 2020 Page.1779-1787

impact of digital media with mediation. Research on parental mediation shows that parents can determine the effect of media on their children ${ }^{(6)}$.

Parental supervision and guidance is the key to counteracting the negative effects of digital media. The use of media is often a source of negotiation between children and their parents. In some families, negotiations about the use of media have been well internalized, but in other children there are parental rules that do not please the child ${ }^{(6)}$.

Research related to mediation generally explains that mediation refers to interactions with children regarding media. Many individuals can mediate, such as brother or sister, friends, and adults, but this term is often used to describe parent-child interactions ${ }^{(12)}$. Parental mediation is the act of interpreting, discussing, and recognizing ideas, images, and information with children. Mothers mediate more often than fathers. In another study, it was found that mothers regulate their children's interactions with digital media use more strictly than fathers do ${ }^{(13)}$. Studies on parental mediation are mostly focused on elementary school children because at elementary school age, the relationship between children and parents is generally powerful and is a strong significant bond ${ }^{(14)}$.

There are three forms of mediation, namely active mediation, restrictive mediation, and co-viewing. Active mediation includes positive active mediation, meaning that parents accompany children during gadget use and tell children about positive things; negative active mediation, meaning that parents tell children negative things from the media used; and neutral mediation, meaning that parents do not provide positive or negative directions, but provide additional information to the child ${ }^{(15)}$.

Restrictive mediation is that parents limit children's access to digital media (gadgets). Parents set their children's watch hours, selected programs, watch time, and others. Meanwhile, in the interviewing mediation, parents assist children when using gadgets. Restrictive mediation was related to less favorable attitudes toward parents, more positive attitudes toward the content, and more viewing of the content with friends. Co-viewing related to both more positive attitudes toward and viewing of television violence and sex $(16,17)$.

\section{Self-efficacy in parental mediation}

The current study showed that media digital literacy program significantly improved the mother's self-efficacy in parental mediation. Mother needs the confidence to operate safely in a digital environment ${ }^{(11)}$. Parental engagement in children's school activities strongly affected their digital parenting self-efficacy. Other sociodemographic and socioeconomic factors (i.e., gender, education, race/ethnicity), mobile Internet access, parents' homework help, and educational expectations fail to contribute ${ }^{(18)}$.

Self-efficacy can be obtained, studied, and developed from four sources of information, which is the stimulation of task achievement. The sources of self-efficacy are experiences of success, others' (role models), verbal persuasion, and physical and emotional conditions (19). One of the ways to get self-efficacy is through a group process with the formation of self-help groups. A group of mothers of school-aged children is exposed to gadgets, so it is compatible with secondary prevention in community nursing. Secondary prevention emphasizes early diagnosis and measures to inhibit the disease process. Activities undertaken include stress management by expressing feelings and joint progressive muscle relaxation and sharing experiences in parental mediation activities. The positive effect obtained is the awakening of the mother's expectations because she realizes that other people experience the same problem. This group is also a forum for sharing information, not only health information related to parental mediation ${ }^{(20)}$. 


\section{STRADA Jurnal Ilmiah Kesehatan}

DOI: $10.30994 /$ sjik.v9i2.522

ISSN: 2252-3847 (print); 2614-350X (online)

Vol.9 No.2 November 2020 Page.1779-1787

Education carried out through this group process has a positive impact on increasing mothers' knowledge, attitudes, and skills in parental mediation activities. This behavioral domain is an indicator of literacy. The literacy level achieved in this program is limited to levels 1 and 2, namely, functional and interactive nutritional literacy ${ }^{(21)}$. Program participant mothers can apply basic literacy skills, namely reading and understanding digital messages and further literacy skills that include interactions to seek and use information in increasing parental mediation efforts.

Parent beliefs about how well the parent is a necessary component to understanding how their beliefs, actual parenting behaviors, and parent-child interactions are aligned ${ }^{(22)}$. How confident a parent considers themselves is receiving increased attention by researchers because of the impact these parenting beliefs can have on children's gadget use.

Parents provide care to protect children from harm that includes boundaries for the child's safety and others; parent-child interactions that support developmental, emotional, and physical health; and enhancing a child's ${ }^{(22)}$. arents who feel more confident in their role as a parent perceive themselves as being effective in their parenting role and are more likely to engage in successful parenting practices. Nursing research is uniquely positioned to study complex phenomena that address health outcomes and promote positive behaviors such as helping to create more efficacious parents. As researchers, our intent needs to produce informative, sound, and theoretically based evidence that enhances the health, well-being, and quality of life for those in our care. Nurses inform care that will lead to improved health outcomes and enhance parents' and their children's quality of life. The more that is known about what helps parents become confident in their role as parents will positively impact the health and development of their child but the potential to influence the well-being of the whole family ${ }^{(22)}$. Maternal self-efficacy was predicted by remembered maternal care as mediated by global self-esteem ${ }^{(23)}$

\section{CONCLUSION}

This research highlights one of the critical issues related to parental mediation in contemporary societies. It recommends formulating a media digital literacy program, considering parental mediation activity. Research suggests launching a community-based program to educate parents, children, and communities on practical parental mediation and safer internet practices.

\section{ACKNOWLEDGMENT}

The researcher would like to thank The Indonesian Ministry of Research, Technology and Higher Education (Ristekdikti) for providing research funds. College of Karya Husada Semarang also supported this work. Thanks to Nature Elementary School Ar-Ridho Semarang in Semarang, that encouraged this work as well.

\section{CONFLICT OF INTERESTS}

The authors do not have any conflicts of interest to disclose.

\section{REFERENCES}

1. Asosiasi Penyelenggara Jasa Internet Indonesia. Penetrasi \& Profil Perilaku Pengguna Internet Indonesia. Apjii [Internet]. 2017;51. Available from: https://apjii.or.id/survei2018s/download/TK5oJYBSyd8iqHA2eCh4FsGELm3ubj

2. Wita MMNA, Khasanah AN, Rahayu MS. Tipe Parental Mediation dan Adiksi Internet Siswa Kelas V SD X Bandung. Psympathic J Ilm Psikol. 2018;5(2):221-30. 


\section{STRADA Jurnal Ilmiah Kesehatan}

DOI: $10.30994 /$ sjik.v9i2.522

ISSN: 2252-3847 (print); 2614-350X (online)

Vol.9 No.2 November 2020 Page.1779-1787

3. adi tri nugroho. Pola Pengawasan Orang Tua Terhadap Aktivitas Anak di Dunia Maya : Studi Kasus Pada Keluarga dengan Anak Remaja Usia 12 - 19 Tahun di Purwokerto. J Ilmu Komun Acta Diurna; Vol 13 No 2 [Internet]. 2017 Oct 31; Available from: http://jos.unsoed.ac.id/index.php/acta_diurna/article/view/604

4. Suraya. Pelatihan Pemberdayaan Sikap Orang Tua Preventif terhadap Dampak Negatif Konten Media Televisi Berbayar di R uang Publik Terpadu Ramah Anak "Cempaka" di Rawa Buaya, Jakarta Barat. J Abdi MOESTOPO. 2018;01(02):30-7.

5. Novianti D, Fatonah S. Literasi Media Digital di Lingkungan Ibu-Ibu Rumah Tangga di Yogyakarta. J Ilmu Komun. 2018;16(1):1.

6. Armando NM, Hendriyani. Pengaruh Mediasi Orangtua Terhadap Afinitas Televisi dan Lama Menonton Televisi pada Anak. InterAct. 2012;1(2):11-20.

7. Bates RA, Salsberry PJ, Justice LM, Dynia JM, Logan JAR, Gugiu MR, et al. Relations of Maternal Depression and Parenting Self-Efficacy to the Self-Regulation of Infants in Low-Income Homes. J Child Fam Stud [Internet]. 2020;29(8):2330-41. Available from: https://doi.org/10.1007/s10826-020-01763-9

8. Dürager A, Sonck N. Testing the reliability of scales on parental internet mediation. EU Kids Online [Internet]. 2014; Available from: eukidsonline.net

9. Özsoy N. Socio-Demographic Differences in Parental Monitoring of Children in Late Childhood and Adolescents' Screen-Based Media Use. J Broadcast Electron Media. 2016 May 16;60:195-212.

10. Vittrup B, Snider S, Rose K, Rippy J. Parental perceptions of the role of media and technology in their young children's lives. J Early Child Res. 2014 Apr 15;14.

11. Suwana F, Lily. Empowering Indonesian women through building digital media literacy. Kasetsart J Soc Sci [Internet]. 2017;38(3):212-7. Available from: http://www.sciencedirect.com/science/article/pii/S2452315117303818

12. Šmahelová M, Juhová D, Cermak I, Smahel D. Mediation of young children's digital technology use: The parents' perspective. Cyberpsychology J Psychosoc Res Cybersp. 2017 Jan $1 ; 11$.

13. Chang F-C, Chiu C-H, Chen P-H, Chiang J-T, Miao N-F, Chuang H-Y, et al. Children's use of mobile devices, smartphone addiction and parental mediation in Taiwan. Comput Human Behav [Internet]. 2019;93:25-32. Available from: http://www.sciencedirect.com/science/article/pii/S0747563218305831

14. Catherine O, Pandia WSS, Pristinella D. Exploring Parental Mediation of Elementary School-Aged Children's Gadget Use. International Conference on Psychology and Multiculturalism 2017. Indonesia; 2017. p. 134-45.

15. Rasmussen E, White SR, King AJ, Holiday S, Densley RL. Predicting parental mediation behaviors: The direct and indirect influence of parents' critical thinking about media and attitudes about parent-child interactions. J Media Lit Educ [Internet]. 2016;8(82):1-21. Available from: www.jmle.org

16. Nathanson A. The Unintended Effects of Parental Mediation of Television on Adolescents. Media Psychol. 2002 Aug 1;4:207-30.

17. Nelissen S, Van den Bulck J. Expanding the Unidirectional View on Parental Television Mediation: Children's Guidance of Their Parent's Television Use. J Broadcast Electron Media [Internet]. 2018 Apr 3;62(2):232-50. Available from: https://doi.org/10.1080/08838151.2018.1451855

18. Huang G, Li X, Chen W, Straubhaar JD. Fall-Behind Parents? The Influential Factors on Digital Parenting Self-Efficacy in Disadvantaged Communities. Am Behav Sci [Internet]. 2018 May 4;62(9):1186-206. Available from: 


\section{STRADA Jurnal Ilmiah Kesehatan}

DOI: $10.30994 /$ sjik.v9i2.522

ISSN: 2252-3847 (print); 2614-350X (online)

Vol.9 No.2 November 2020 Page.1779-1787

https://doi.org/10.1177/0002764218773820

19. Guntzviller LM, King AJ, Jensen JD, Davis LA. Self-Efficacy, Health Literacy, and Nutrition and Exercise Behaviors in a Low-Income, Hispanic Population. J Immigr Minor Heal. 2017 Apr;19(2):489-93.

20. Iqbal S, Zakar R, Fischer F. Predictors of parental mediation in teenagers' internet use: A cross-sectional study of female caregivers in Lahore, Pakistan. 2020;

21. Guttersrud O, Dalane JØ, Pettersen S. Improving measurement in nutrition literacy research using Rasch modelling: examining construct validity of stage-specific "critical nutrition literacy" scales. Public Health Nutr. 2014 Apr;17(4):877-83.

22. Vance AJ, Brandon DH. Delineating Among Parenting Confidence, Parenting SelfEfficacy, and Competence. ANS Adv Nurs Sci [Internet]. 2017;40(4):E18-37. Available from: https://pubmed.ncbi.nlm.nih.gov/28825934

23. Leerkes EM, Crockenberg SC. The Development of Maternal Self-Efficacy and Its Impact on Maternal Behavior. Infancy [Internet]. 2002;3(2):227-47. Available from: https://doi.org/10.1207/S15327078IN0302_7 